\title{
Parking Space Needs Analysis Tamini Square Mall and Performance Roadway Pondok Gede, Jakarta
}

\author{
Widodo Budi Dermawan and Bagas Pradita \\ Faculty of Engineering, University of Mercu Buana Jakarta, Indonesia \\ wbdermawan@gmail.com, bagaspradita88@gmail.com
}

\begin{abstract}
Jakarta is the capital city of Indonesia with a population of 10.46 million inhabitants (CBS, 2018). Tamini Square Mall located in East Jakarta has a population of approximately 2,916,018 people (BPS, 2018). Tamini Square Mall is a mall located in East Jakarta, precisely at the Crossroads Taman Mini Raya and Jalan Raya Pondok Gede were established in 2006. The total area of approximately 1,000 meter ${ }^{2}$ consisting of 5 floors. Tamini Square Mall became one of the popular shopping center due to its strategic location and within walking distance of Pinang Ranti Terminal, Settlements, Central Offices, Schools and Recreation Taman Mini Indonesia Indah. The method used in this research is by way of observation. Observation method is a method by means of direct survey of spaciousness. It is absolutely necessary to know the actual conditions. The survey method is dilakukuan on this analysis, a method of recording the number of vehicles. Accumulation of the largest parking for cars on Sunday as many as 120 vehicles occurred between 16:00 to $16: 59 \mathrm{pm}$, while on Sunday for a motor vehicle 382 takes place between 14:00 to 14:59 pm. The average duration of parking of vehicles is 4 hours 24 minutes for cars and 4 hours 18 minutes for the motor. The parking index was $89.55 \%$ for cars occurred on Sunday at 16:00 to 16:59 pm and 88.84 for motorcycles occurred on Sunday at 14:00 to 14:59 pm. The Turn Over parking is 3 vehicles / SRP / time observations for cars and 4 vehicle / SRP / observation time for the motor and it happened on a Sunday. Judging from the analysis Roads Raya Pondok Gede, East Jakarta for speed survey at peak hours in the morning, afternoon and evening in getting the level of service or Level of Service (LOS), namely C and D.
\end{abstract}

Keyword: index parking, parking needs, level of service.

\section{Introduction}

Tamini Square Mall is a mall located in East Jakarta located precisely at the junction of Jalan Taman Mini Raya and Jalan Raya Pondok Gede operational in 2006. Built with modern architecture to occupy a land area of approximately 1,000 meter $^{2}$ consisting of 5 floors. Tamini Square Mall became one of the popular shopping center due to its strategic location and within walking distance of Pinang Ranti Terminal, Settlements, Central Offices, Schools and Recreation Taman Mini Indonesia Indah.

The problems of this study include: 1). What is the capacity of existing parking spaces and whether the need for parking spaces in Tamini Square Mall, this time is enough to accommodate the vehicles meet? 2). How characteristic parking parking in the form of volume, the accumulated parking, parking index, duration of parking and parking turnover (turnover) in Tamini Square Mall? 3). How alternative solutions to tackle the problem of parking in Tamini Square Mall? 4). How is the performance of road in front of the mall Tamini square jakarta?

\section{Methodology}

\subsection{Data Collection Methods}

a) Observations or observation includes observations of various matters relating to the physical condition and activity at the study site.

b) Documentation refers to the gathering and assessment of some information from periodicals, books, literature documents, photographs, newspapers, electronic media and statistical references.

\subsection{Method of Data Processing and Data Analysis}

Methods of data processing and data analysis used in this research is qualitative descriptive analysis by considering the field survey on parking duration, the accumulated volume of parking, parking capacity, parking index, use of parking space and parking space requirements. In addition it also used the standards and guidelines for the planning and operation of parking facilities. As for the performance of road by taking into account the results of a field survey on the data traffic volume, the data side friction, road capacity (C) and Q / C ratio, speed survey of traffic, speed based MKJI 1997, and Service Level (Level OF Service). 


\subsection{Flowchart}

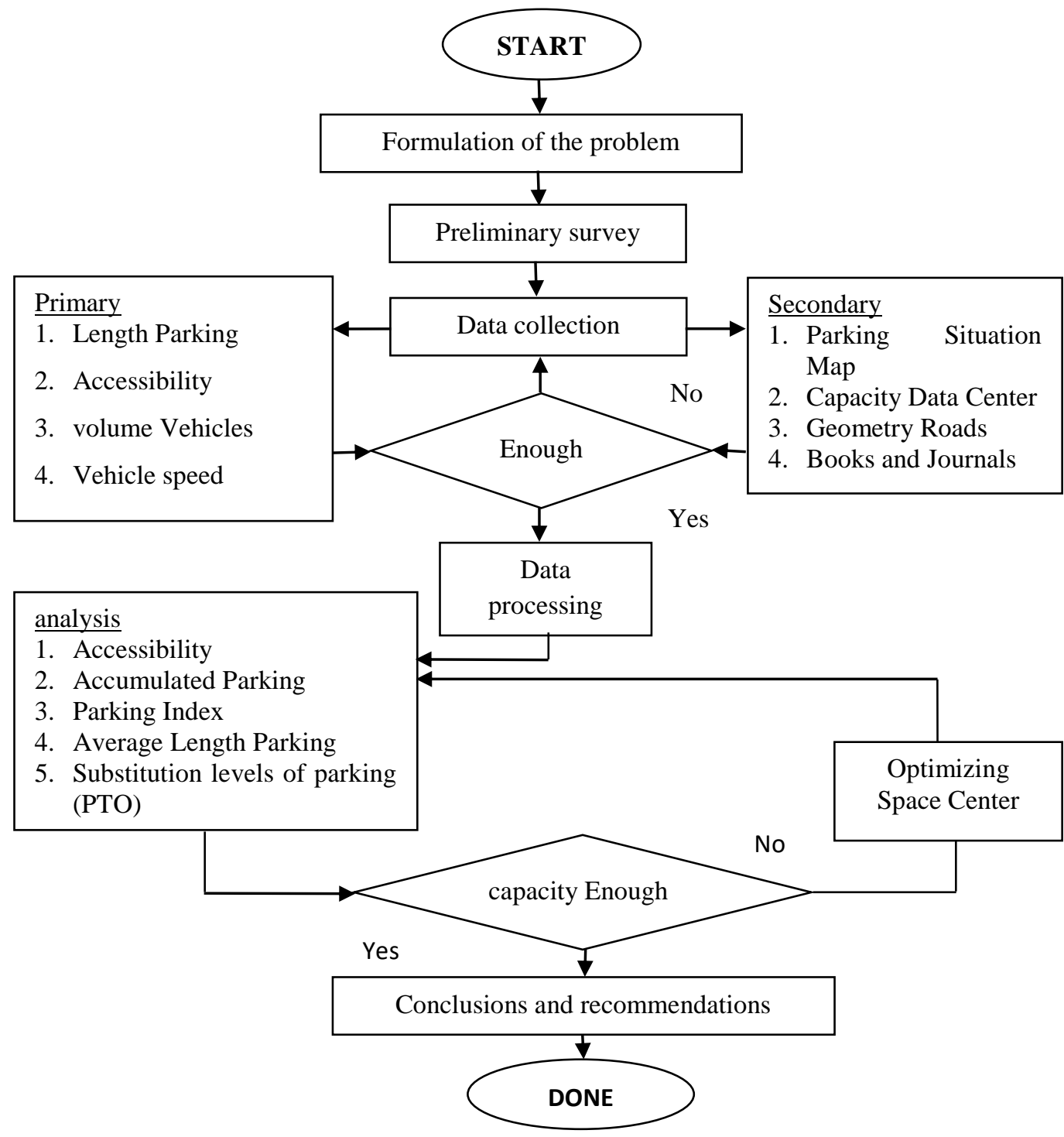

Figure 1. Flowchart of Research

(Source: Processed Author, 2019)

\section{Results and Analysis}

\section{1 characteristics Parking}

From the data that has been obtained, then the processing of the data as follows:

\subsubsection{Volume parking}

Parking volume is the number of vehicles that have been using the parking space at a particular parking space in a certain time (usually per day). 
Table 1. Volume Car Parking and motors Friday 22 November 2019

\begin{tabular}{ccccc}
\hline \multirow{2}{*}{ Time } & \multicolumn{2}{c}{ Car } & \multicolumn{2}{c}{ Motorcycle } \\
& entry & Exit & entry & Exit \\
\hline$<10: 00$ & 12 & 0 & 34 & 0 \\
10:00 to 10:59 & 5 & 4 & 62 & 49 \\
11:00 to 11:59 a.m. & 12 & 8 & 71 & 32 \\
12:00 to 12:59 & 18 & 16 & 76 & 54 \\
13:00 to 13:59 & 25 & 27 & 78 & 52 \\
14:00 to 14:59 & 19 & 18 & 56 & 67 \\
15:00 to 15:59 & 11 & 12 & 46 & 51 \\
16:00 to 16:59 & $\mathbf{4 7}$ & 16 & 77 & 71 \\
5:00 p.m. to 5:59 p.m. & 36 & 28 & $\mathbf{8 7}$ & 68 \\
18:00 to 18:59 & 21 & 31 & 69 & 73 \\
19:00 to 19:59 & 28 & $\mathbf{4 2}$ & 52 & 79 \\
20:00 to 20:59 & 24 & 34 & 45 & $\mathbf{1 1 3}$ \\
21:00 to 21:59 & 6 & 28 & 18 & 62 \\
$>$ 22:00 & 0 & 0 & 0 & 0 \\
\hline TOTAL & $\mathbf{2 6 4}$ & $\mathbf{2 6 4}$ & $\mathbf{7 7 1}$ & $\mathbf{7 7 1}$ \\
\hline
\end{tabular}

Source: Processed Author, 2019

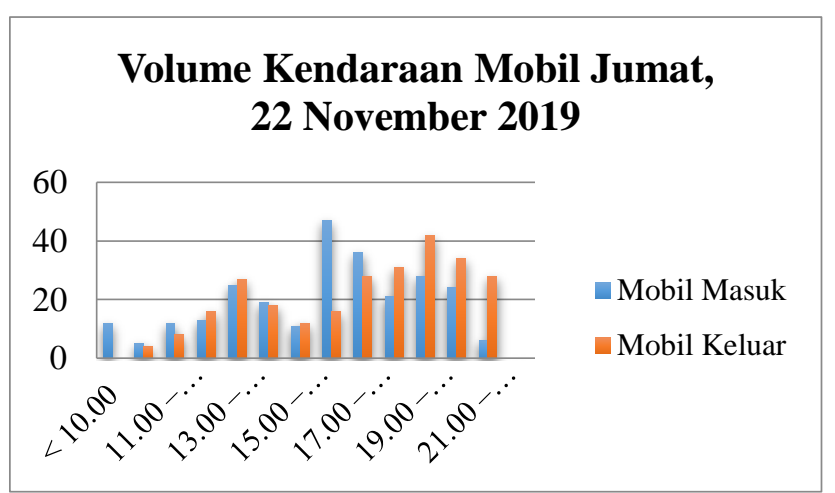

Figure 2. Graph Volume Car Parking On Friday, 22 November 2019

Source: Processed Author, 2019 


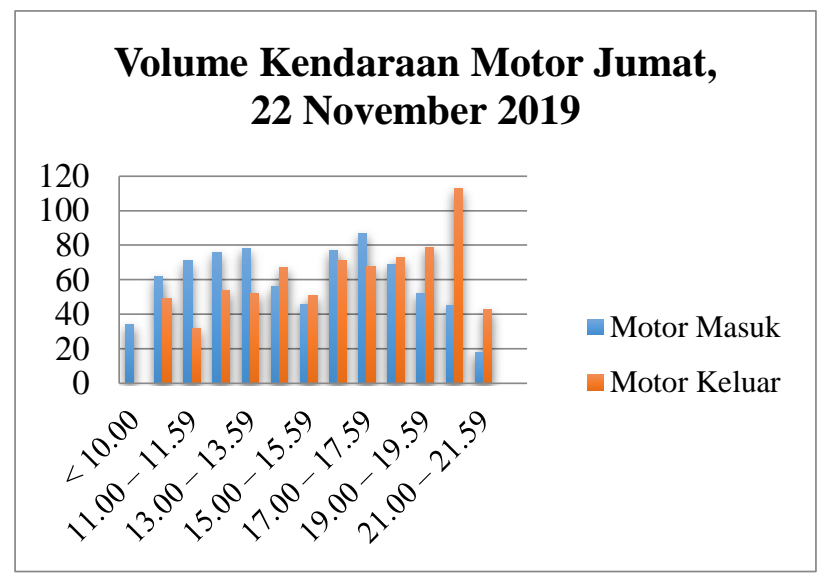

Figure 3. Volume Graphics Mo Parkingtor Saturday, 22 November 2019

Source: Processed Author, 2019

Table 2. Volume parking Cars and Motorcycle Day Saturday 23 November 2019

\begin{tabular}{ccccc}
\hline Time & \multicolumn{3}{c}{ Car } & \multicolumn{2}{c}{ Motorcycle } \\
& entry & Exit & entry & Exit \\
\hline$<10: 00$ & 14 & 0 & 53 & 0 \\
10:00 to $10: 59$ & 21 & 19 & 125 & 77 \\
11:00 to 11:59 & 26 & 17 & 153 & 94 \\
a.m. & 31 & 21 & 124 & 112 \\
12:00 to 12:59 & 23 & 37 & 168 & 97 \\
13:00 to 13:59 & 27 & 26 & 141 & 103 \\
14:00 to 14:59 & 31 & 18 & 129 & 99 \\
15:00 to 15:59 & $\mathbf{4 7}$ & 25 & 132 & 93 \\
16:00 to 16:59 & 34 & 27 & $\mathbf{1 9 6}$ & 178 \\
5:00 p.m. to 5:59 & 29 & 39 & 101 & 157 \\
p.m. & 26 & 29 & 76 & 174 \\
18:00 to 18:59 & 11 & $\mathbf{4 6}$ & 48 & $\mathbf{2 0 2}$ \\
19:00 to 19:59 & 7 & 23 & 22 & 82 \\
20:00 to 20:59 & 0 & 0 & 0 & 0 \\
21:00 to 21:59 & $\mathbf{3 2 7}$ & $\mathbf{3 2 7}$ & $\mathbf{1 4 6 8}$ & $\mathbf{1 4 6 8}$ \\
\hline 22:00 & TOTAL & $\mathbf{3 2}$
\end{tabular}

Source: Processed Author, 2019

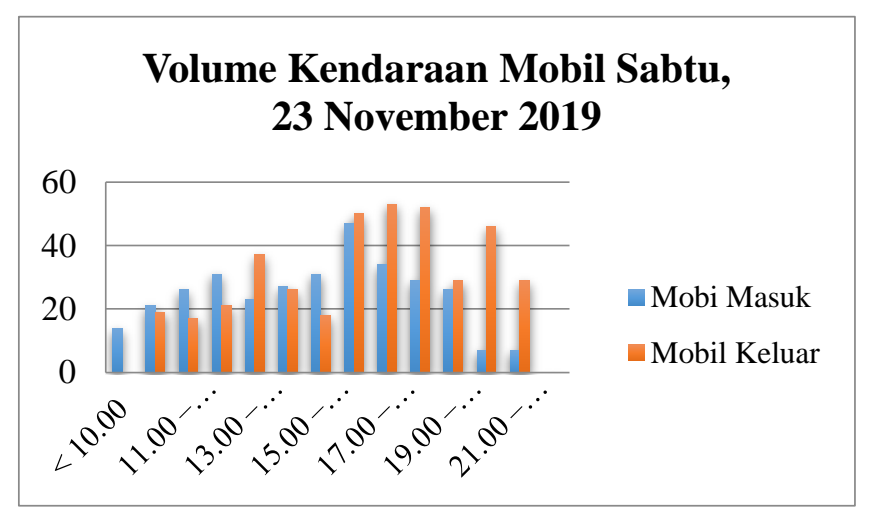

Figure 4. The Volume Graph M Parkingobil Saturday, November 232019 Source: Processed Author, 2019 
Table 4, Accumulated Parking Cars and Motorcycles

Day Saturday 23 November 2019

\begin{tabular}{|c|c|c|c|c|c|c|}
\hline \multirow{2}{*}{ Time } & \multicolumn{2}{|c|}{ Car } & \multirow{2}{*}{$\begin{array}{c}\text { Accumulated } \\
\text { Parking }\end{array}$} & \multicolumn{2}{|c|}{ Motorcycle } & \multirow{2}{*}{$\begin{array}{l}\text { Accumulated } \\
\text { Parking }\end{array}$} \\
\hline & entry & Exit & & entry & Exit & \\
\hline$<10: 00$ & 14 & 0 & 14 & 53 & 0 & 53 \\
\hline $10: 00$ to $10: 59$ & 21 & 19 & 16 & 125 & 77 & 101 \\
\hline $\begin{array}{c}11: 00 \text { to } 11: 59 \\
\text { a.m. }\end{array}$ & 26 & 17 & 25 & 153 & 94 & 160 \\
\hline $12: 00$ to $12: 59$ & 31 & 21 & 35 & 124 & 112 & 172 \\
\hline $13: 00$ to $13: 59$ & 23 & 37 & 21 & 168 & 97 & 243 \\
\hline $14: 00$ to $14: 59$ & 27 & 26 & 22 & 141 & 103 & 281 \\
\hline $15: 00$ to $15: 59$ & 31 & 18 & 35 & 129 & 99 & 311 \\
\hline $16: 00$ to $16: 59$ & 47 & 25 & 57 & 132 & 93 & 350 \\
\hline $\begin{array}{l}\text { 5:00 p.m. to } \\
\text { 5:59 p.m. }\end{array}$ & 34 & 27 & 64 & 196 & 178 & 368 \\
\hline $18: 00$ to $18: 59$ & 29 & 39 & 54 & 101 & 157 & 312 \\
\hline $19: 00$ to $19: 59$ & 26 & 29 & 51 & 76 & 174 & 214 \\
\hline $20: 00$ to $20: 59$ & 11 & 46 & 16 & 48 & 202 & 60 \\
\hline $21: 00$ to $21: 59$ & 7 & 23 & 0 & 22 & 82 & 0 \\
\hline$>22: 00$ & 0 & 0 & 0 & 0 & 0 & 0 \\
\hline TOTAL & 327 & 327 & & 1468 & 1468 & \\
\hline
\end{tabular}

Source: Processed Author, 2019

\section{Akumulasi Parkir Sabtu, 23 November}

2019

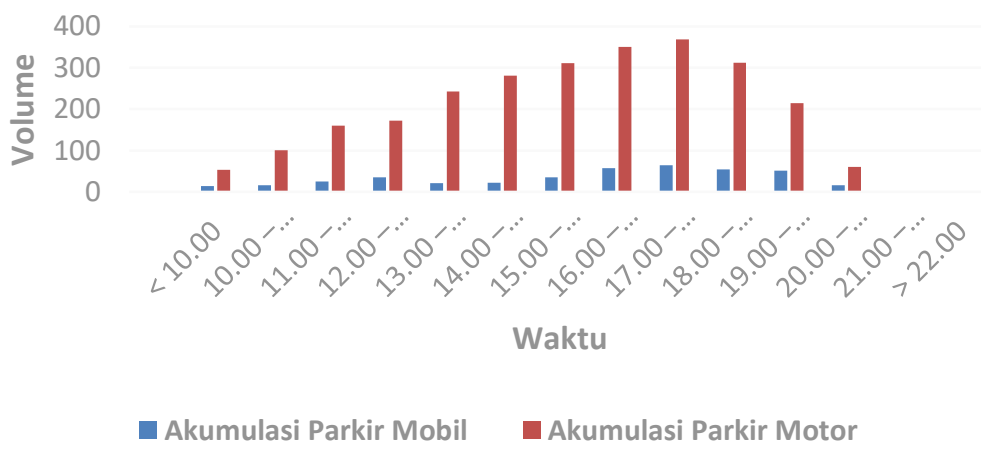

Figure 7. Graph Accumulated Car Parking and Motorcycle Day Saturday, 23 November 2019

Source: Processed Author, 2019

\subsubsection{Parking Index}

Parking index is the ratio between the accumulation of vehicles parked in parking capacity available. Parking index is used to determine whether the number of parking plots available at the study site comply or not to accommodate the parking of vehicles. 
Table 5. Index and Motor Car Parking Friday 22 November 2019

\begin{tabular}{ccccccc}
\hline Time & $\begin{array}{c}\text { Accumulated } \\
\text { Car Parking }\end{array}$ & $\begin{array}{c}\text { Index } \\
\text { Car } \\
\text { Parking }\end{array}$ & $\begin{array}{c}\text { Availability } \\
\text { of parking }\end{array}$ & $\begin{array}{c}\text { Accumulated } \\
\text { Parking } \\
\text { Motor }\end{array}$ & $\begin{array}{c}\text { Index } \\
\text { Motorcycle } \\
\text { Parking }\end{array}$ & $\begin{array}{c}\text { Availability } \\
\text { of parking }\end{array}$ \\
\hline$<10: 00$ & 12 & $8.96 \%$ & $91.04 \%$ & 34 & $7.91 \%$ & $92.09 \%$ \\
10:00 to 10:59 & 13 & $9.70 \%$ & $90.30 \%$ & 47 & $10.93 \%$ & $89.07 \%$ \\
11:00 to 11:59 a.m. & 17 & $12.69 \%$ & $87.31 \%$ & 86 & $20.00 \%$ & $80.00 \%$ \\
12:00 to 12:59 & 19 & $14.18 \%$ & $85.82 \%$ & 108 & $25.12 \%$ & $74.88 \%$ \\
13:00 to 13:59 & 17 & $12.69 \%$ & $87.31 \%$ & 134 & $31.16 \%$ & $68.84 \%$ \\
14:00 to 14:59 & 18 & $13.43 \%$ & $86.57 \%$ & 123 & $28.60 \%$ & $71.40 \%$ \\
15:00 to 15:59 & 17 & $12.69 \%$ & $87.31 \%$ & 118 & $27.44 \%$ & $72.56 \%$ \\
16:00 to 16:59 & 48 & $35.82 \%$ & $64.18 \%$ & 124 & $28.84 \%$ & $71.16 \%$ \\
5:00 p.m. to 5:59 p.m. & 56 & $\mathbf{4 1 . 7 9 \%}$ & $58.21 \%$ & 143 & $\mathbf{3 3 . 2 6 \%}$ & $66.74 \%$ \\
18:00 to 18:59 & 46 & $34.33 \%$ & $65.67 \%$ & 139 & $32.33 \%$ & $67.67 \%$ \\
19:00 to 19:59 & 32 & $23.88 \%$ & $76.12 \%$ & 112 & $26.05 \%$ & $73.95 \%$ \\
20:00 to 20:59 & 22 & $16.42 \%$ & $83.58 \%$ & 44 & $10.23 \%$ & $89.77 \%$ \\
21:00 to 21:59 & 0 & 0 & $100 \%$ & 0 & 0 & $100 \%$ \\
$>$ 22:00 & 0 & 0 & $100 \%$ & 0 & 0 & $100 \%$ \\
\hline
\end{tabular}

Source: Processed Author, 2019

Table 6. Index and Motor Car Parking

Day Saturday, November 23, 2019

\begin{tabular}{|c|c|c|c|c|c|c|}
\hline Time & $\begin{array}{l}\text { Accumulated } \\
\text { Car Parking }\end{array}$ & $\begin{array}{l}\text { Index Car } \\
\text { Parking }\end{array}$ & $\begin{array}{c}\text { Availability of } \\
\text { parking }\end{array}$ & $\begin{array}{l}\text { Accumulated } \\
\text { Parking Motor }\end{array}$ & $\begin{array}{c}\text { Index } \\
\text { Motorcycle } \\
\text { Parking }\end{array}$ & $\begin{array}{l}\text { Availability of } \\
\text { parking }\end{array}$ \\
\hline$<10: 00$ & 14 & $10.45 \%$ & $89.55 \%$ & 53 & $12.33 \%$ & $87.67 \%$ \\
\hline $\begin{array}{c}10: 00 \text { to } \\
10: 59\end{array}$ & 16 & $11.94 \%$ & $88.06 \%$ & 101 & $23.49 \%$ & $76.51 \%$ \\
\hline $\begin{array}{l}11: 00 \text { to } \\
\text { 11:59 a.m. }\end{array}$ & 25 & $18.66 \%$ & $81.34 \%$ & 160 & $37.21 \%$ & $62.79 \%$ \\
\hline $\begin{array}{c}12: 00 \text { to } \\
12: 59\end{array}$ & 35 & $26.12 \%$ & $73.88 \%$ & 172 & $40.00 \%$ & $60.00 \%$ \\
\hline $\begin{array}{c}13: 00 \text { to } \\
13: 59\end{array}$ & 21 & $15.67 \%$ & $84.33 \%$ & 243 & $56.51 \%$ & $43.49 \%$ \\
\hline $\begin{array}{c}14: 00 \text { to } \\
14: 59\end{array}$ & 22 & $16.42 \%$ & $83.58 \%$ & 281 & $65.35 \%$ & $34.65 \%$ \\
\hline $\begin{array}{c}15: 00 \text { to } \\
15: 59\end{array}$ & 35 & $26.12 \%$ & $73.88 \%$ & 311 & $72.33 \%$ & $27.67 \%$ \\
\hline $\begin{array}{c}16: 00 \text { to } \\
16: 59\end{array}$ & 57 & $42.54 \%$ & $57.46 \%$ & 350 & $81.40 \%$ & $18.60 \%$ \\
\hline $\begin{array}{c}\text { 5:00 p.m. } \\
\text { to 5:59 } \\
\text { p.m. }\end{array}$ & 64 & $47.76 \%$ & $52.24 \%$ & 368 & $85.58 \%$ & $14.42 \%$ \\
\hline $\begin{array}{c}18: 00 \text { to } \\
18: 59\end{array}$ & 54 & $40.30 \%$ & $59.70 \%$ & 312 & $72.56 \%$ & $27.44 \%$ \\
\hline $\begin{array}{l}19: 00 \text { to } \\
19: 59\end{array}$ & 51 & $38.06 \%$ & $61.94 \%$ & 214 & $49.77 \%$ & $50.23 \%$ \\
\hline $\begin{array}{l}20: 00 \text { to } \\
20: 59\end{array}$ & 16 & $11.94 \%$ & $88.06 \%$ & 60 & $13.95 \%$ & $86.05 \%$ \\
\hline $\begin{array}{l}21: 00 \text { to } \\
21: 59\end{array}$ & 0 & $0,00 \%$ & $0,00 \%$ & 0 & $0,00 \%$ & $0,00 \%$ \\
\hline$>22: 00$ & 0 & $0,00 \%$ & $0,00 \%$ & 0 & $0,00 \%$ & $0,00 \%$ \\
\hline
\end{tabular}


Indeks Parkir Jumat, 22 November 2019

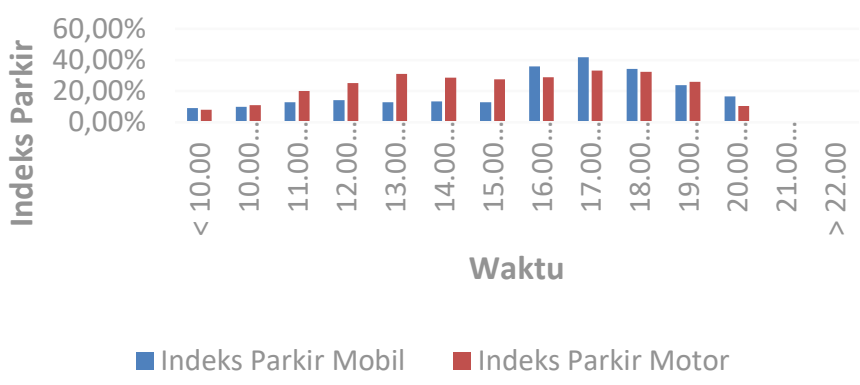

Figure 8. Graph Index and Motor Car Parking On Friday, 22 November 2019

Source: Processed Author, 2019

Indeks Parkir Sabtu, 23 November 2019

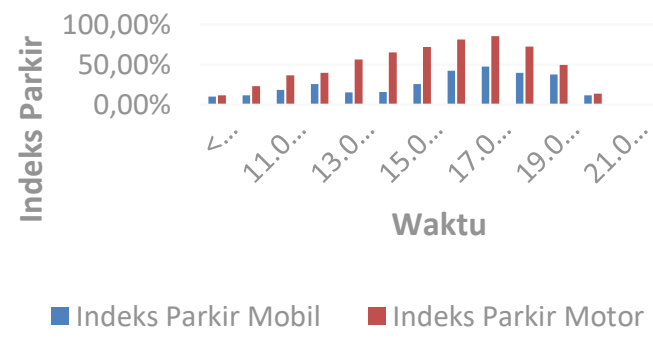

Figure 9. Graph index Car Parking and Motorcycle Saturday, 23 November 2019

Source: Processed Author, 2019

\subsubsection{Length Parking}

The average duration of the parking time is the average time used by each vehicle in the parking facilities.

Table 7. Length Car Parking and Motor

Friday 22 November 2019

\begin{tabular}{ccccc}
\hline $\begin{array}{c}\text { Parking Duration } \\
\text { (Hours) }\end{array}$ & $\begin{array}{c}\text { Number of } \\
\text { vehicles }\end{array}$ & $\begin{array}{c}\text { Car } \\
\text { Length Parking } \mathbf{x} \text { Number } \\
\text { of Vehicles }\end{array}$ & $\begin{array}{c}\text { Number of } \\
\text { vehicles }\end{array}$ & $\begin{array}{c}\text { Motorcycle } \\
\text { Length Parking x Number } \\
\text { of Vehicles }\end{array}$ \\
\hline 1 & 34 & 34 & 172 & 172 \\
2 & 66 & 132 & $\mathbf{2 3 4}$ & 468 \\
3 & $\mathbf{7 1}$ & 213 & 157 & 471 \\
4 & 28 & 112 & 36 & 144 \\
5 & 15 & 75 & 41 & 195 \\
6 & 11 & 66 & 33 & 112 \\
7 & 7 & 49 & 16 & 184 \\
8 & 9 & 72 & 23 & 153 \\
9 & 8 & 72 & 17 & 190 \\
10 & 9 & 90 & 19 & 121 \\
11 & 3 & 33 & 11 & 84 \\
12 & 1 & 12 & 7 & 65 \\
13 & 2 & 26 & 5 & $\mathbf{2 5 6 7}$ \\
\hline
\end{tabular}

Source: Processed Author, 2019 
VOLUME 2 | NUMBER 2 | MARCH 2020

Available online at http://proceedings.worldconference.id.

ISSN: 2656-1174 (online)

Table 8. Duration parking Motor

Saturday 23 November 2019

\begin{tabular}{|c|c|c|c|c|}
\hline $\begin{array}{l}\text { Parking Duration } \\
\text { (Hours) }\end{array}$ & \multicolumn{2}{|r|}{ Car } & \multicolumn{2}{|r|}{ Motorcycle } \\
\hline 1 & 56 & 56 & 324 & 324 \\
\hline 3 & 51 & 153 & 198 & 594 \\
\hline 4 & 49 & 196 & 133 & 532 \\
\hline 5 & 32 & 160 & 151 & 755 \\
\hline 7 & 21 & 147 & 61 & 427 \\
\hline 8 & 18 & 144 & 87 & 696 \\
\hline 9 & 6 & 54 & 43 & 387 \\
\hline 10 & 13 & 130 & 54 & 540 \\
\hline 11 & 8 & 88 & 22 & 242 \\
\hline 12 & 6 & 72 & 19 & 228 \\
\hline
\end{tabular}

Source: Processed Author, 2019

\subsubsection{Parking Space Needs}

Parking space requirement is the result of the calculation of the duration of the parking lot into an equation to determine the needs of each parking space vehicles parked.

Table 9. Parking Space Needs Tamini Square Mall

\begin{tabular}{cccccccc}
\hline $\begin{array}{c}\text { Day and Time } \\
\text { Survey }\end{array}$ & $\begin{array}{c}\text { Transportation } \\
\text { type }\end{array}$ & $\begin{array}{c}\text { Short Time } \\
\text { Parking (SRP) }\end{array}$ & $\%$ & $\begin{array}{c}\text { Parking Time } \\
\text { Medium (SRP) }\end{array}$ & \% & $\begin{array}{c}\text { Old Time } \\
\text { Parking } \\
\text { (SRP) }\end{array}$ & $\%$ \\
\hline $\begin{array}{c}\text { Friday, } \\
\text { November 22, }\end{array}$ & Motorcycle & 50.76 & 37.88 & 50.25 & 37.50 & 32.99 & 24.62 \\
2019 & 226.43 & 52.66 & 107.64 & 25.03 & 95.93 & 22.31 \\
$\begin{array}{c}\text { Saturday, } \\
\text { November 23, }\end{array}$ & $\begin{array}{c}\text { Car } \\
\text { Motorcycle }\end{array}$ & 41.39 & 30.89 & 40.98 & 30.58 & 51.63 & 38,53 \\
2019 & & 178.97 & 41.62 & 96.96 & 22.55 & 154.07 & 35.83 \\
\hline
\end{tabular}

Source: Processed Author, 2019

\subsubsection{Substitution levels of parking (Parking Turn Over / PTO)}

Parking turnover rate will indicate the level of use of the parking spaces are obtained by dividing the number of vehicles parked during the time of observation.

a) Substitution level parking / Parking Turn Over (PTO) for a car that is:

1. PTO on the day of Friday, November 22, 2019

$\mathrm{PTO}=264 / 134=1.97 \approx 2$ vehicle $/$ SRP

2. PTO on a Saturday, November 23, 2019

$\mathrm{PTO}=327 / 134=2.44 \approx 2$ vehicle $/ \mathrm{SRP}$

b) Substitution level parking / Parking Turn Over (PTO) for the motor, namely:

1. PTO on the day of Friday, November 22, 2019

$\mathrm{PTO}=771 / 430=1.79 \approx 2$ vehicle $/ \mathrm{SRP}$

2. PTO on a Saturday, November 23, 2019

$\mathrm{PTO}=1468 / 430=3.41 \approx 3$ vehicle $/ \mathrm{SRP}$

\subsubsection{Parking capacity}

Parking space capacity is the maximum capacity of the space to accommodate the vehicle, in this case the vehicle volume users such parking facilities.

a. Capacity for car parking, namely:

1. Parking capacity on the day of Friday, November 22, 2019

$\mathrm{KP}=134 / 3.7=36$ vehicles $/$ hour 
2. The capacity of the park on Saturday, November 23, 2019

$\mathrm{KP}=134 / 4.4=30$ vehicles $/$ hour

b. Parking capacity for the motor, namely:

1. Parking capacity on the day of Friday, November 22, 2019

$\mathrm{KP}=430 / 3.3=129$ vehicles $/$ hour

2. The capacity of the park on Saturday, November 23, 2019

$\mathrm{KP}=430 / 4.0=107$ vehicles $/$ hour

\subsubsection{Parking Space Needs Analysis 5 (Five) Years Future}

To determine the need for parking spaces on Tamini Square Mall within the next 5 years, the variables that influence the economic growth in the city East Jakarta, Based on data from the Central Statistics Agency (BPS)East Jakarta, The economic growth rate by an average of $6.22 \%$ Per year, while the volume of cars and motor vehicles used the largest volume in 2019. This figure can be used to estimate how long the car parking spaces and motorcycle parking spaces Tamini Square Mall can accommodate the number of vehicle volume annually.

a) vehicles Cars

\section{Growth forecasts Parking $=$ Accumulated Vehicles $(1+\text { Growth })^{n}$}

The volume of automobiles in $2019=327$ vehicle

Car parking spaces are available $=134$ SRP

Parking growth forecasts $\quad=327 \times(1+0.062) 5$

$=327 \times 1.35$

$=442$ (Rounded)

Thus, the volume of automobiles in 2024 is expected to increase to 442 vehicle.

b) Motorcycle

Volume of motor vehicles in $2019=1468$ vehicles

Car parking spaces are available $=430 \mathrm{SRP}$

Parking growth forecasts $\quad=1468 \times(1+0.062) 5$

$$
=1468 \times 1.35
$$

$=1982($ Rounded $)$

Thus, the volume of motor vehicles in 2024 is expected to increase to 1982 vehicle.

\subsection{Roads}

\subsubsection{Traffic Volume}

Traffic data obtained from the results of the field survey at peak hours by counting the number of vehicles every 15 minutes for 2 hours in the morning, 15 minutes for 2 hours during the day, and 15 minutes for 2 hours in the afternoon. The number of vehicles converted into passenger car unit (smp) according to the type of vehicles that pass through JalanRaya Pondok Gede,

Table 10. Maximum Vehicle Traffic Volume Day Friday, November 22, 2019

\begin{tabular}{ccccc}
\hline \multirow{2}{*}{ Period } & $\begin{array}{c}\text { Friday, November 22, 2019 } \\
\text { Jalan Raya Pondok Gede }\end{array}$ & \multicolumn{2}{c}{ Total } \\
& veh / h & smp / hour & veh / h & smp / hour \\
\hline Morning (07:00 to 9:00) & 4314 & 2757.6 & 4314 & 2757.6 \\
Lunch (11:00 to 13:00) & 3068 & 2001.5 & 3068 & 2001.5 \\
Afternoon (14:00 to 18:00) & 4524 & 2655.6 & 4524 & 2655.6 \\
\hline
\end{tabular}

Source: Processed Author, 2019

Table 11. Maximum Vehicle Traffic Volume Day Friday, November 22, 2019

\begin{tabular}{|c|c|c|c|c|}
\hline \multirow{3}{*}{ Period } & \multicolumn{4}{|c|}{ Saturday, November 23, 2019} \\
\hline & \multicolumn{2}{|c|}{ Jalan Raya Pondok Gede } & \multicolumn{2}{|c|}{ Total } \\
\hline & veh / h & smp / hour & veh / h & smp / hour \\
\hline Morning (07:00 to $9: 00)$ & 4410 & 2695.2 & 4410 & 2695.2 \\
\hline Lunch (11:00 to $13: 00)$ & 4556 & 2897.9 & 4556 & 2897.9 \\
\hline Afternoon (14:00 to $18: 00)$ & 4648 & 2768.5 & 4648 & 2768.5 \\
\hline
\end{tabular}




\section{Volume Kendaraan Maksismum}

Jumat, 22 November 2019

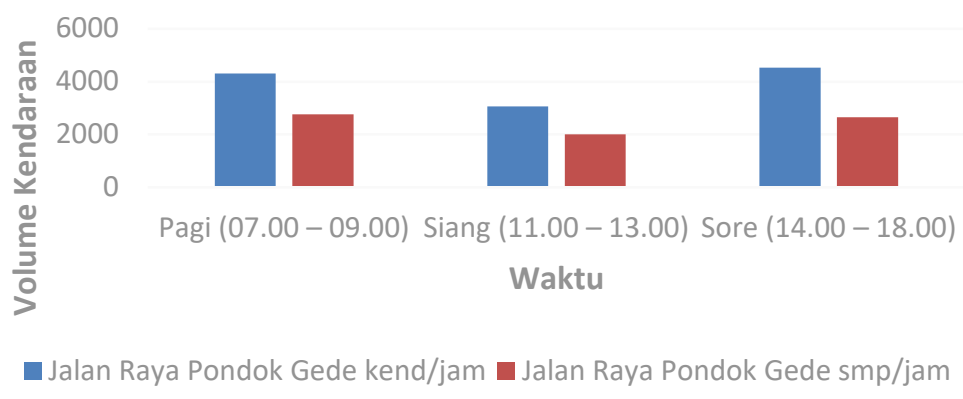

Figure 10. Graph Maximum Volume Vehicle On Friday, 22 November 2019

Source: Processed Author, 2019

Volume Kendaraan Maksismum

Sabtu, 23 November 2019

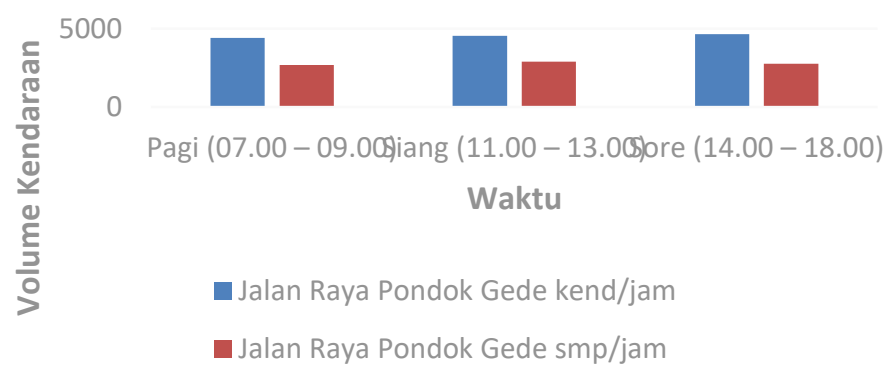

Figure 11. Maximum Vehicle Volume Graph Saturday, 23 November 2019

Source: Processed Author, 2019

\subsubsection{Barriers Side}

Data obtained from the side barriers field survey at peak hours by counting the number of side barriers every 15 minutes for 2 hours in the morning, 15 minutes for 2 hours during the day, and 15 minutes for 2 hours in the afternoon.

Table 12. Maximum Volume Side Barriers

\begin{tabular}{ccccc}
\hline \multirow{2}{*}{ Period } & \multicolumn{2}{c}{ Friday, November 22, 2019 } & \multicolumn{2}{c}{ Saturday, November 23, 2019 } \\
\cline { 2 - 5 } & veh / h & smp / hour & veh / h & smp / hour \\
\hline Morning (07:00 to 9:00) & 244 & 155.2 & 288 & 204.3 \\
Lunch (11:00 to 13:00) & 176 & 114.2 & 259 & 177.9 \\
Afternoon (14:00 to 18:00) & 252 & 176.5 & 287 & 202.5 \\
\hline
\end{tabular}

Source: Processed Author, 2019

\subsubsection{Road capacity (C) and Q / C Ratio}

The capacity of urban roads can be determined from the following formula:

C $=$ Co $\times$ FCsp FCW $\times \times \times$ FCsf FCCS

Where :

$\mathrm{C}=$ Capacity (smp / hour)

Co = Capacity basic (smp / hour)

FCW = Lane width adjustment factor

FCsp = Adjustment factor dividing direction

FCsf = Side friction adjustment factor 
FCCS = City size adjustment factor

Then the value of $\mathrm{C}$ ratio can be determined by calculation as follows:

Then the value of $\mathrm{C}$ ratio can be determined by calculation as follows:

C $=$ Co $\times$ FCsp FCW $\times \times \times$ FCsf FCCS

$\mathrm{C}=4950 \times 1,00 \times 1,00 \times 0,97 \times 1,00$

$\mathrm{C}=4801.5 \mathrm{smp} /$ hour

Table 13. Capacity of RoadsRaya Pondok Gede

\begin{tabular}{|c|c|c|c|c|}
\hline \multirow{2}{*}{ variables } & \multicolumn{4}{|c|}{ Jalan Raya Pondok Gede } \\
\hline & Adjustment factor & Morning & daylight & Afternoon \\
\hline Co & Divided road (3 lanes) / 1 way & 4950 & 4950 & 4950 \\
\hline FCW & Not Divided Lane road width $3.5 \mathrm{~m}$ & 1 & 1 & 1 \\
\hline FCsp & Jalan 3/1 & 1 & 1 & 1 \\
\hline FCsf & $\begin{array}{c}\text { Side Barriers class Medium (M), width of } \\
2 \mathrm{~m} \text { Effective Sidewalks, Street Not } \\
\text { Divided 3/1 }\end{array}$ & 0.97 & 0.97 & 0.97 \\
\hline FCCS & $\begin{array}{c}\text { East Jakarta Population 2,916,018 Million } \\
\text { People }\end{array}$ & 1 & 1 & 1 \\
\hline $\mathrm{C}$ & & 4801.5 & 4801.5 & 4801.5 \\
\hline
\end{tabular}

Source: Processed Author, 2019

Table 14. Q / C ratio of Roads Raya Pondok Gede Friday 22 Nov2019 bucket

\begin{tabular}{ccccc}
\hline Period & Q & \multicolumn{2}{c}{ Friday, November 22, 2019 } \\
& C & Q / C & LOS \\
\hline Morning (07:00 to 9:00) & 4314 & 4801.5 & 0.90 & D \\
Lunch (11:00 to 13:00) & 3068 & 4801.5 & 0.64 & B \\
Afternoon (16:00 to 18:00) & 4524 & 4801.5 & 0.94 & E \\
\hline
\end{tabular}

Source: Processed Author, 2019

Table 15. Q / C ratio of Roads Raya Pondok Gede Saturday 23 Nov2019 bucket

\begin{tabular}{ccccc}
\hline Period & \multicolumn{4}{c}{ Saturday, November 23, 2019 } \\
Q & C & Q / C & LOS \\
\hline Morning (07:00 to 9:00) & 4314 & 4801.5 & 0.92 & E \\
Lunch (11:00 to 13:00) & 4556 & 4801.5 & 0.95 & E \\
Afternoon (16:00 to 18:00) & 4648 & 4801.5 & 0.97 & E \\
\hline
\end{tabular}

Source: Processed Author, 2019

\subsubsection{Speed Traffic Survey Results}

The following survey data traffic speeds at peak hours at each segment is complete, the results of the primary data collection in the field can be seen in the calculation of average speed of the vehicle based on a sample 3 light / 15 minutes unless there is a data error (values are too different).

Table 16. Free Resume

\begin{tabular}{ccccc}
\hline & \multicolumn{3}{c}{ Jalan Raya Pondok Gede } & \\
TIME & Friday, November 22, 2019 & Saturday, November 23, 2019 \\
\cline { 2 - 5 } Speed & LOS & Speed & LOS \\
Morning (07:00 to 9:00) & 32,50 & C & 31.08 & D \\
Lunch (11:00 to 13:00) & 42.13 & B & 29.60 & D \\
Afternoon (16:00 to 18:00) & 30.73 & D & 28.05 & D \\
\hline
\end{tabular}

Source: Processed Author, 2019

\subsubsection{Based on the speed of MKJI 1997}

Free flow speed using light vehicles as the primary measure of performance. According MKJI 1997, the equation for the free flow speed has the following general form: 


\section{$F V=($ FV0 + FVW $) \times$ FFVSF $x$ FFVCS}

Where :

FV $\quad=$ Free flow speed of light vehicles in field conditions $(\mathrm{km} / \mathrm{h})$

$\mathrm{FV0}=$ Basic free flow speed of light vehicles $(\mathrm{km} / \mathrm{h})$

$\mathrm{FVW}=$ Adjustment speed for the road width $(\mathrm{km} / \mathrm{h})$

FFVSF $=$ Adjustment factor due to the side barriers

FFVCS $=$ City size adjustment factor

Thus, value FV is: $\mathrm{FV}=(\mathrm{FV} 0+\mathrm{FVW}) \times \mathrm{FFVSF} \times \mathrm{FFVCS}$

$$
\begin{aligned}
& \mathrm{FV}=(61+10.5) \times 0.98 \times 1.00 \\
& \mathrm{FV}=70.07 \mathrm{~km} / \mathrm{h}
\end{aligned}
$$

\begin{tabular}{|c|c|c|}
\hline \multicolumn{3}{|c|}{ Friday, November 22, 2019} \\
\hline \multicolumn{2}{|c|}{ Information } & Jalan Raya Pondok Gede \\
\hline & Morning (07:00 to 9:00) & 70.07 \\
\hline Free Flow velocity (FV) & Lunch (11:00 to $13: 00)$ & 70.07 \\
\hline $\mathrm{km} / \mathrm{h}$ & $\begin{array}{c}\text { Afternoon (16:00 to } \\
18: 00)\end{array}$ & 70.07 \\
\hline \multirow{3}{*}{$\begin{array}{l}\text { The degree of saturation } \\
\qquad(\mathrm{Q} / \mathrm{C})\end{array}$} & Morning (07:00 to 9:00) & 0.90 \\
\hline & Lunch (11:00 to $13: 00)$ & 0.64 \\
\hline & $\begin{array}{c}\text { Afternoon (16:00 to } \\
18: 00)\end{array}$ & 0.94 \\
\hline \multirow{4}{*}{$\begin{array}{l}\mathrm{VLV} \\
\mathrm{km} / \mathrm{h}\end{array}$} & Morning (07:00 to 9:00) & 52.3 \\
\hline & Lunch $(11: 00$ to $13: 00)$ & 64.7 \\
\hline & $\begin{array}{c}\text { Afternoon (16:00 to } \\
18: 00)\end{array}$ & 48.4 \\
\hline & Source: Processed Author & \\
\hline \multicolumn{3}{|c|}{ Table 18. Results of Determining the Value VLV Day Saturday, November 23, 2019} \\
\hline \multicolumn{3}{|c|}{ Saturday, November 23, 2019} \\
\hline \multicolumn{2}{|c|}{ Information } & Jalan Raya Pondok Gede \\
\hline \multirow{4}{*}{$\begin{array}{l}\text { Free Flow velocity (FV) } \\
\qquad \mathrm{km} / \mathrm{h}\end{array}$} & Morning (07:00 to 9:00) & 70.07 \\
\hline & Lunch (11:00 to $13: 00)$ & 70.07 \\
\hline & $\begin{array}{c}\text { Afternoon (16:00 to } \\
18: 00)\end{array}$ & 70.07 \\
\hline & Morning (07:00 to 9:00) & 0.92 \\
\hline \multirow{2}{*}{$\begin{array}{l}\text { The degree of saturation } \\
\text { (Q / C) }\end{array}$} & Lunch $(11: 00$ to $13: 00)$ & 0.95 \\
\hline & $\begin{array}{c}\text { Afternoon (16:00 to } \\
18: 00)\end{array}$ & 0.97 \\
\hline \multirow{3}{*}{$\begin{array}{l}\mathrm{VLV} \\
\mathrm{km} / \mathrm{h}\end{array}$} & Morning (07:00 to 9:00) & 50.2 \\
\hline & Lunch (11:00 to $13: 00)$ & 48.1 \\
\hline & $\begin{array}{c}\text { Afternoon (16:00 to } \\
18: 00)\end{array}$ & 46.2 \\
\hline
\end{tabular}

Table 17. Results of Determining the Value VLV Day Friday, November 22, 2019

Source: Processed Author, 2019

\subsubsection{Service Level (Level of Services)}

The service levels can be determined by calculating the volume of traffic with the basic capacity (Q / C. By performing the calculation of the value of the Ombudsman, it is known classification of the road or the level of service on a particular road segment. 


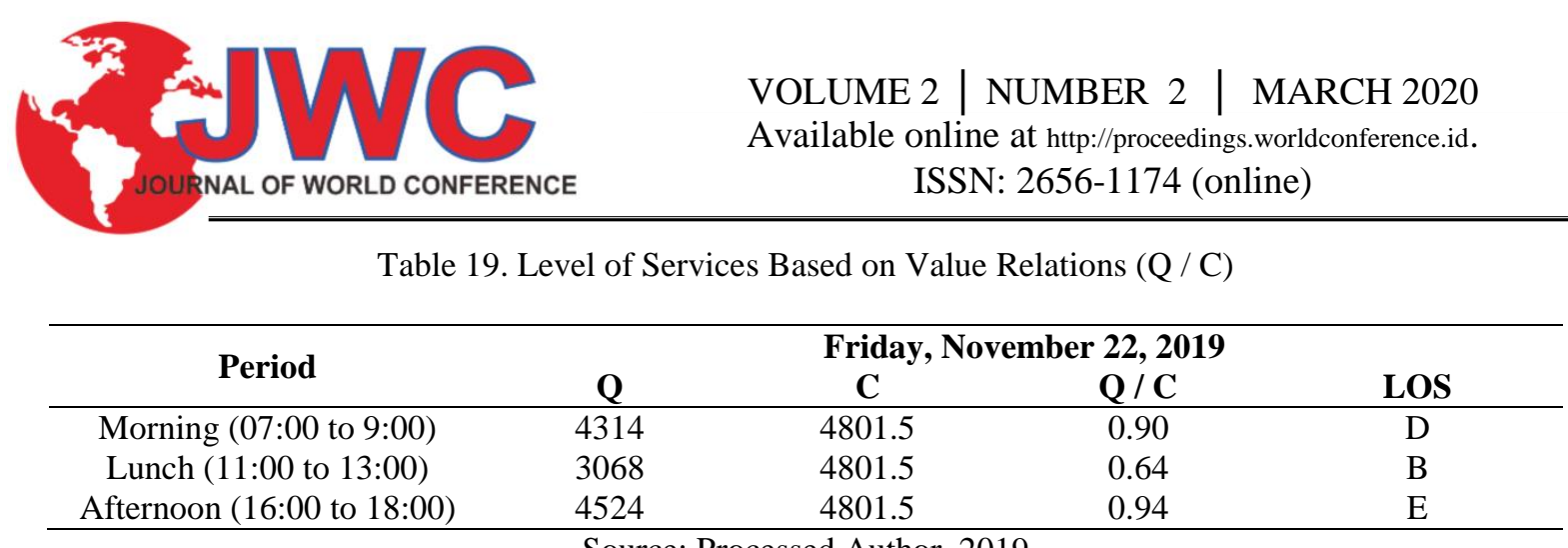

Source: Processed Author, 2019

Table 20. Level of Services Based on Value Relations (Q / C)

\begin{tabular}{ccccc}
\hline Period & \multicolumn{4}{c}{ Saturday, November 23, 2019 } \\
Q & C & Q / C & LOS \\
\hline Morning (07:00 to 9:00) & 4410 & 4801.5 & 0.92 & E \\
Lunch (11:00 to 13:00) & 4556 & 4801.5 & 0.95 & E \\
Afternoon (16:00 to 18:00) & 4648 & 4801.5 & 0.97 & E \\
\hline
\end{tabular}

Source: Processed Author, 2019

\section{Conclusion}

Based on the survey results and analysis of the characteristics in the parking lot Tamini Square Mall in previous discussions, the results are as follows:

1. Parking space capacity in Tamini Square Mall,

a) The number of entrances and exits to the car park, namely:

1) 2 entrance to the car park area.

2) 2 exit of the car park area.

b) The number of entrances and exits to the parking of motor, namely:

1) 1 entrance to the parking area of the motor.

2) 1 exit motorcycle parking area.

c) Parking Space Unit size (SRP) for cars Tamini Square Mall has dimensions of 2.50 x 4.90 (95\% of BSLLAK 1998) with a total capacity amounted to 134 SRP.

d) Parking Space Unit size (SRP) for the motor in Tamini Square Mall has dimensions of 0.75 x 1.90 (95\% of BSLLAK 1998 ) with a total capacity amounted to 430 SRP.

2. Car parking space requirements in Tamini Square Mall, JakartaTimur on Friday 22 November 2019 and Saturday 23 November2019 can still meet to accommodate the vehicles. It is known from the parking index value of $41.79 \%$ for cars and parking index with a value of $33.26 \%$ for a motor vehicle that occurred on Friday22 November 2019. For Parking index with a value of $47.76 \%$ for cars and parking index with a value of $85.58 \%$ for a motor vehicle that occurred on Saturday 23 November 2019.

3. Characteristics parking in Tamini Square Mall,

a) The volume of vehicles

1) Friday, 22 November 2019

Cars: 264 vehicles

Motor: 771 vehicles

2) Saturday, 23 November 2019

Cars: 327 vehicles

Motor: 1468 vehicles

b) Accumulated Parking

1) Friday, 22 November 2019

Car: 56 vehicles occurred between the hours of 5:00 p.m. to 17:59 pm.

Motor: 143 vehicles occurred between the hours of 5:00 p.m. to 17:59 pm.

2) Saturday, 23 November 2019

Car: 64 vehicles occurred between the hours of 5:00 p.m. to 17:59 pm.

Motor: 368 vehicles occurred between the hours of 5:00 p.m. to 17:59 pm.

c) Average duration of parking

1) Friday, 22 November 2019

Cars: The average duration of the car park at 3 hours 42 minutes. 
Motor: The average duration of the motor park of 3 hours 18 minutes.

2) Saturday, 23 November 2019

Cars: The average duration of the car park for 4 hours 24 minutes.

Motor: The average duration of the motor park of 4 hours 0 minutes.

So that belong to the middle and long parkers parkers.

d) Parking Index

1) Friday, 22 November 2019

Car: parking index of $41.79 \%$ occurred at 17:00 to $17: 59 \mathrm{pm}$.

Motor: parking index of $33.26 \%$ occurred at 17:00 to $17: 59 \mathrm{pm}$.

2) Saturday, 23 November 2019

Car: parking index of 47.76 struck at 5:00 p.m. to 17:59 pm.

Motor: parking index of $85.58 \%$ occurred at 17:00 to $17: 59 \mathrm{pm}$.

e) Parking Turn Over

1) Friday, 22 November 2019

Car: Parking Turn Over Car by 2 vehicles / SRP.

Motor: Parking Turn Over motors for 2 vehicles / SRP.

2) Saturday, 23 November 2019

Car: Parking Turn Over Car by 2 vehicles / SRP.

Motor: Parking Turn Over motors for 3 vehicles / SRP.

4. Performance Roads Raya Pondok Gede

A. From the analysis of Roads Raya Pondok Gede which has been done:

1) Friday, 22 November 2019

a) The morning average level of service or Level of Service (LOS) that D in hours 07:00 to 09:00 with a degree of saturation value is 0.90 .

b) During the day the average level of service or Level of Service (LOS) that is in hours 11:00 to 13:00 with a degree of saturation value is 0.64 .

c) Sore day average level of service or Level of Service (LOS) is E in hours 16:00 to 18:00 with a degree of saturation value is 0.94 .

2) Saturday, 23 November 2019

a) The morning average level of service or Level of Service (LOS) is E in hours 07:00 to 09:00 with a degree of saturation value is 0.92 .

b) During the day the average level of service or Level of Service (LOS) is E in hours 11:00 to 13:00 with a degree of saturation value is 0.95 .

c) Sore day average level of service or Level of Service (LOS) is E in hours 16:00 to 18:00 with a degree of saturation value is 0.97 .

B. Judging from the survey speed of service level or Level of Service (LOS) on Roads Raya Pondok Gede which has been carried out on:

1) Friday, 22 November 2019

a) Morning service level or Level of Service (LOS) is C.

b) During the day the level of service or Level of Service (LOS) is B.

c) The afternoon service level or Level of Service (LOS) is D.

2) Saturday, 23 November 2019

a) Morning service level or Level of Service (LOS) is D.

b) During the day the level of service or Level of Service (LOS) is C.

c) The afternoon service level or Level of Service (LOS) is D. 


\section{Reference}

[1] Anonymous (1993). Government Regulation No. 43 of 1993 on Road Traffic and Infrastructure, Jakarta.

[2] Anonymous, (1996). Directorate General of Land Transportation. Guidelines. Technical Operation of parking facilities. Jakarta.

[3] Anonymous (1997). Highway Capacity Manual Indonesia, Jakarta.

[4] BPS East Jakarta, (2018). Statistics of CityEast Jakarta 2018, 